\title{
Evaluating Drama Activities on Fifth Grade Science Subjects with the Developed Analytical Rubric ${ }^{i}$
}

\author{
Pınar Ural Keleş ${ }^{1, *}$, Salih Çepni ${ }^{2}$ \\ ${ }^{1}$ Faculty of Education, Ağrı İbrahim Çeçen University, Ağrı, Turkey \\ ${ }^{2}$ Faculty of Education, Uludağ University, Bursa, Turkey
}

Copyright $(2019$ by authors, all rights reserved. Authors agree that this article remains permanently open access under the terms of the Creative Commons Attribution License 4.0 International License

\begin{abstract}
In this study, it is aimed to evaluate the drama activities conducted in fifth grade science subjects with a developed analytical rubric. The study was conducted using case study. The sample of the study consists of 26 students attending 5th grade in a public school located in the Akçaabat district of Trabzon province. In the study, four groups were formed from the sample. Eight different drama events were conducted by the groups formed in the study related to the two acquisitions in the fifth class "Classification of living things". The evaluation of the drama activities in the study was decided to be done with process-oriented evaluation. For this purpose, an analytical rubric consisting of performance criteria such as 'scenario', 'content of roles', 'role sharing' and 'role play' has been developed. As a result of the evaluation of the drama activities with analytical rubric, it was concluded that the students were not used to the rubric evaluation and focused on the product rather than the process. One of the suggestions of the study is the inclusion of students in the development process of rubrics in order to understand the performance criteria and levels in the rubric better.
\end{abstract}

Keywords Fifth Grade Science Subjects, Drama, Evaluation of Drama Activities with Analytical Rubrics

\section{Introduction}

In parallel with the rapid developments and innovations in many different fields, modern day education institutions are expected to train individuals who can produce information, use it as functional in life, solve problems, think critically, are entrepreneur, stable, have communication skills, have esthetic view, can make empathy and so on. Therefore, it has become mandatory to use the teaching methods and techniques, which enable the students to acquire the mentioned qualities in the learning environments and make the students active [27].
One of the techniques that makes the student active and enable him / her to gain qualifications due to the age is drama. Adigüzel [1] defines the drama as "enacting any subject with reference to the experiences of a group or with a group by using techniques such as improvisation, role playing." The function of drama in education and training is very important. When drama is used in terms of a game, the main purpose of using it in educational environments is to improve students' cognitive, affective and psychomotor skills by enhancing participation and making them an active subject of the learning process $[15 ; 21 ; 42 ; 37]$.

The of 7-11 period is called the concrete process period according to Piaget, and it is a stage in which children devote themselves to game according to Freud. During this period, called 'Latent period', children enjoy playing games with their peers [39;40]. In this respect, it is unthinkable that teachers do not take advantage of the games in their lessons because the prerequisite for learning is to stimulate emotions, learn by doing and experiencing [52;25;53]. There are games at the core of the drama, which provides students with a learning by living environment [1].

It is known that by using drama in science education, learning will be provided by experience, the concepts of science will be made easy and enjoyable to learn by dramatizing them, motivation will be increased, and abstract science concepts will be facilitated [36;29;50;5]. In addition, it is stated that associating the conceptual understanding facilitated in science education to daily life facilitates problem solving and fast thinking skills [4;3]. In addition, accepting that learning takes place in social environments, which is one of the important points in constructivist approach, can be realized by using drama activities in teaching science subjects [16;51].

It is reported in the literature that it is not easy to score and evaluate alternative measurement tools such as performance task, drama, presentation, project used in order to determine high level cognitive skills such as reading comprehension, problem solving, critical thinking and doing research [18;34]. Different evaluation approaches are needed to evaluate the above-mentioned 
performance tasks [31;34] as these performance tasks involve students' use of high thinking skills and often involve a product [2].

One of the tools used to evaluate different performance tasks of students is the rubrics [18]. Rubrics are a graded scoring system that requires teachers to determine the level of mastery of the performance or subject to which the students can reveal or perform the knowledge of certain subjects [10]. Thanks to the rubrics, the student's level of proficiency in pointing out knowledge of a case, a situation or an issue, or performing a task is scored [8]. The use of rubrics has many benefits for teachers and students. The most important of these are given below [6;14;8;41].

- It enables students to know according to what they are evaluated and what the teachers want from them.

- It saves time while the teacher is evaluating.

- Significant feedback is provided on the students' strengths and weaknesses.

- It provides objectivity as it is certain according to what the evaluation will be done.

- It allows students to monitor their own development process.

- It combines teaching and evaluation.

- In situations where the assessment is carried out by the students, it plays a major role in the student's ability to develop critical thinking, cause-effect relation, interpreting by using data, and being open to new views.

Popham [35] also classifies rubrics by dividing them into two groups in terms of their structural characteristics.

1) Holistic rubric

2) Analytical rubric

Holistic rubrics are the rubrics in which a single score is given to the overall performance. It includes the overall process and the product as a whole, scoring without considering parts. In holistic rubrics, it is determined how many levels will be evaluated. Each level has definitions that determine the quality of performance. For each level, expressions indicating what the student can do are written. Holistic rubrics often have single and general grade performance criteria. Rubrics are used in cases in which performance cannot be disassembled or when it is not possible to perform the evaluation on independent performance criteria. Because it contains less details, it is easy to analyze $[8 ; 46 ; 24]$.

Analytical rubrics are mostly used to measure the procedure and the process leading to the result. Analytical rubrics are preferred especially when the performance to be measured includes multiple dimensions and the levels of performance criteria are observable. These rubrics have more than one grade performance criterion and are intended for any particular purpose. A detailed description of the criteria for each performance criterion is defined. These performance levels contain specific and clear definitions. In the analytical rubrics, the parts that constitute the performance are scored independently according to the criteria determined separately, thus analytical rubrics provide more information than holistic scoring and they are more detailed. Each performance criterion is scored separately, and these points are collected, and the total score is obtained $[20 ; 19 ; 48 ; 46 ; 55 ; 7]$.

It is also stated in different studies that teachers give very little space to rubrics among the methods of evaluation in science courses and that they are insufficient in preparing rubrics $[30 ; 23 ; 45 ; 44 ; 12]$. This point makes the studies on the preparation of rubrics as an assessment tool and their use in different courses.

When the related literature is examined, it is seen that the studies on the subject focus on determining the effects of using drama activities in different courses on success, attitude and conceptual understanding [38;22;13;47]. In the literature, there are no studies on the evaluation of the drama activities in science courses with rubrics. Based on the points mentioned above, the purpose of this study is to evaluate the drama activities in fifth grade science subjects by using the developed rubric. It is thought that the results obtained from the study will contribute to the related field.

\section{Method}

\subsection{Research Design}

Case study was used in this study. The case study allows an in-depth examination and concentration on a particular subject or situation. In this research method, it is aimed to examine the situation in its own flow in its real environment in depth and to describe it in detail [11].

\subsection{Study Group}

The sample of this study consists of 26 students in the 5th grade of a school located in the Akçaabat district of Trabzon

\subsection{Data Collection Tools}

An analytical rubric was developed by the researcher to evaluate the drama activities in this study. In developing the rubric to be used in the study, firstly rubric samples in the literature were examined $[8 ; 41 ; 26 ; 46]$. As is known, there are certain stages to be considered in the development of the rubrics to be used in the evaluation of student performances. While developing the rubric to be used in the study, a new rubric was developed based on the rubric to be used to evaluate the drama activities, which is recommended by Ministry of National Education resources [26]. The rubric preparation steps developed by Airasian [2] and Sezer [41] were used in the development phase of the rubric to be used. These steps are as follows.

- Performance involving a process or product is selected. 
- Performance standards, i.e. criteria, are determined for the process or product

- Performance levels to be used in rubric rating are determined

- Best student performance and other student performances are also defined.

The following path was followed while developing the rubric used in the study according to the above steps.

\section{- $\quad$ Selecting the process or product including the product}

In this step, it is expected to determine the performance behavior that should be observed from students [2;41]. In this study, two acquisitions were determined from the classification of 5th class living things subject and process-oriented evaluation of the drama activities to be made within these acquisitions was decided. The determined acquisitions are "Classifies animals as vertebrates and invertebrates in terms of having / without a backbone" and "Gives examples of the benefits and harms of microscopic creatures." Because the performance to be measured in the drama activities includes multiple dimensions and the performance levels are observable, analytical rubric was decided to be used in the evaluation. As it is known, analytical rubrics are mostly used in evaluating the performance levels of the students during the process [28].

\section{- Determining the performance criteria for selected process or product}

The term performance criteria are used in this research instead of performance criterion such as in the studies of MEB, [26], İpek [19] and Şenel [46]. While determining the performance criteria of the drama activities to be done by the groups, the rubric samples in the literature were examined first $[8 ; 41 ; 26 ; 46]$. Afterwards, the opinions of the subject teacher were discussed after interviewing him. In the study, it was decided to include 'scenario', 'the content of the roles', 'sharing the roles' and 'role play' performance criteria in analytical rubric to be developed to evaluate drama activities.

\section{- Determining performance levels to be used in rubric scoring}

The performance levels performed by the students in the rubric prepared for evaluating the drama activities were categorized and graded. The scoring of the determined performance criteria was between $0-4$ points. For each criterion, the best performance level for each criterion is 0 points and the worst performance level is 4 points.

\section{- Defining the best student performance and other student performance levels}

The best level and other student levels were defined for each of the 'scenario', 'the content of the roles', 'sharing the roles' and 'role play' performance criteria in the analytical rubric. For the different performance criteria in rubric, the best performance level score is 4 and the worst performance level score is 0 .

After developing the analytical rubric to be used in the study, expert opinion was re-applied. Taking expert opinion [14] is one of the most important stages of the development of rubrics. The rubric developed within this study was examined by a field expert, a language expert and a teacher who conducted the course and necessary corrections were made in line with their opinions. The rubric was also examined by six $5^{\text {th }}$ grade students and it was tried to determine whether there were any points not understood, and necessary corrections were made in the rubric according to the feedback.

Analytical rubric developed to evaluate drama activities is given below. 
Table 1. Analytical Rubric Improved to be Used to Evaluate Group No:

\begin{tabular}{|c|c|c|c|c|c|c|}
\hline \multirow{2}{*}{$\begin{array}{l}\text { Performance } \\
\text { criteria }\end{array}$} & \multicolumn{5}{|c|}{ Performance levels } & \multirow[b]{2}{*}{ Score } \\
\hline & 4 points & 3 points & 2 points & 1 points & 0 points & \\
\hline Scenario & $\begin{array}{l}\text { 1. The subject of the scenario was } \\
\text { completely appropriate, and the } \\
\text { information provided was correct and } \\
\text { satisfying. }\end{array}$ & $\begin{array}{l}\text { 1. The subject of the scenario was } \\
\text { appropriate to the purpose and the } \\
\text { information provided was } \\
\text { generally satisfactory. }\end{array}$ & $\begin{array}{l}\text { 1. The subject of the scenario was } \\
\text { appropriate for its purpose, but the } \\
\text { information given was not } \\
\text { satisfactory. }\end{array}$ & $\begin{array}{l}\text { 1. The subject of the scenario } \\
\text { was not appropriate to its } \\
\text { purpose. }\end{array}$ & $\begin{array}{l}\text { There was no } \\
\text { preparation. }\end{array}$ & \\
\hline $\begin{array}{l}\text { Content of } \\
\text { roles }\end{array}$ & $\begin{array}{l}\text { 1. All of the roles in the game fully } \\
\text { reflect the story and purpose. } \\
\text { 2. Proper preparations were made for } \\
\text { the roles. }\end{array}$ & $\begin{array}{l}\text { 1. The majority of the roles in the } \\
\text { game fully reflect the story and } \\
\text { purpose. } \\
\text { 2. Proper preparations were made } \\
\text { for the roles. }\end{array}$ & $\begin{array}{l}\text { 1. A few of the roles in the game fully } \\
\text { reflected the story and purpose. } \\
2 \text {. Very few preparations were made } \\
\text { for the roles. }\end{array}$ & $\begin{array}{l}\text { 1. None of the roles in the } \\
\text { game fully reflected the story } \\
\text { and purpose. } \\
\text { 2. Proper preparations were } \\
\text { made for the roles. }\end{array}$ & $\begin{array}{l}\text { There was no } \\
\text { preparation. }\end{array}$ & \\
\hline $\begin{array}{l}\text { Sharing the } \\
\text { roles }\end{array}$ & $\begin{array}{l}\text { 1. In the group, the role-sharing was } \\
\text { done well, and all the students had } \\
\text { different roles in play. }\end{array}$ & $\begin{array}{l}\text { 1. Role-sharing was done in the } \\
\text { group, and most of the students had } \\
\text { different roles in play. }\end{array}$ & $\begin{array}{l}\text { 1. Role-sharing was done in the } \\
\text { group, but very few of the students } \\
\text { had different roles in the game. }\end{array}$ & $\begin{array}{l}\text { 1. There was no role-sharing in } \\
\text { the group and some of the } \\
\text { students had roles. }\end{array}$ & $\begin{array}{l}\text { There was no } \\
\text { preparation. }\end{array}$ & \\
\hline Role play & $\begin{array}{l}\text { 1. The role play of everyone in the } \\
\text { group was remarkable. } \\
2 . \text { The language and gestures used by } \\
\text { the group members in the role play } \\
\text { were effective and appropriate. } \\
\text { 3. At the end of the event, the group's } \\
\text { answers to the questions were all true. } \\
\text { 4. Group effectively used presentation } \\
\text { time. }\end{array}$ & $\begin{array}{l}\text { 1. The role play of everyone in the } \\
\text { group was remarkable. } \\
\text { 2. The language and gestures used } \\
\text { by the group members in the role } \\
\text { play were effective and } \\
\text { appropriate. } \\
\text { 3. At the end of the event, most of } \\
\text { the group's answers to the } \\
\text { questions were true. } \\
\text { 4. Group effectively used } \\
\text { presentation time. }\end{array}$ & $\begin{array}{l}\text { 1. The role play of a few members of } \\
\text { the group was remarkable. } \\
\text { 2. The language and gestures used by } \\
\text { a few of the group members were } \\
\text { effective and appropriate. } \\
\text { 3. At the end of the event, a few of the } \\
\text { group's answers to the questions were } \\
\text { true. } \\
\text { 4. Group effectively used } \\
\text { presentation time. }\end{array}$ & $\begin{array}{l}\text { 1. The role play of the group } \\
\text { members was not remarkable. } \\
\text { 2. The language and gestures } \\
\text { by the group members in the } \\
\text { role play were not effective } \\
\text { and appropriate. } \\
\text { 3. At the end of the event, all of } \\
\text { the group's answers to the } \\
\text { questions were wrong. } \\
\text { 4. Group effectively used } \\
\text { presentation time. }\end{array}$ & $\begin{array}{l}\text { There was no } \\
\text { preparation. }\end{array}$ & \\
\hline
\end{tabular}




\subsection{Implementation}

\subsubsection{Developing the Drama Activities}

Within the scope of this study, the researcher who conducted the study first tried to establish a comprehensive infrastructure about the subject by completing the 252-hour training program given by local and foreign experts who are experts in the field of the use of drama in educational activities. While determining the subjects in which drama activities would be performed, the subjects within the scope of classification of living things were examined and it was tried to determine which ones were suitable for drama activities. At this stage, an expert conducting undergraduate drama courses and a teacher were interviewed about the subjects determined for the drama activities and they were consulted how to do drama activities on these subjects. Within the study, it was decided to perform drama activities related to the two acquisitions. Another reason for choosing these acquisitions for drama activities is that there are a lot of misconceptions in the subject at every age level $[17 ; 43 ; 54 ; 9 ; 49]$. The pilot study of the developed drama activities was carried out in another fifth grade. During the implementation of the drama studies to be done in the pilot work, the deficiencies and unclear points were determined and corrected.

\subsubsection{Application of Drama Activities}

Before the study, a mini meeting was held on how to do drama activities with the teacher. Twenty-six students were divided into 4 groups like 7-7-6-6 according to the teacher's opinions. Although it was determined that the students conducted drama studies in Turkish courses in the previous years, a free drama study was conducted by the researcher in a lesson observed by the teacher before the practice. While the original drama activities were conducted with the teacher, the researcher attended the class as an observer. Within the framework of two subjects, eight different drama activities were conducted by four groups.

In the first part of the study, drama activities were conducted within the scope of the acquisition of 'classifies the animals as vertebrates and invertebrates in terms of having / without a backbone'.

Before the activities, a story was read by the teacher about different vertebrates and invertebrates, the story was interrupted to arouse curiosity. The groups were asked to complete the story with different vertebrates or invertebrates and to role play the completed story. The given part of the story was prepared by using animals with misconceptions about vertebrates. Groups were given a week to study.

The second drama activity conducted within the scope of the study is related to the acquisition of 'Gives examples of the benefits and harms of microscopic organisms'. Two of the groups were asked to role play the benefits of microscopic creatures in our daily lives and the other two were asked to role paly the damage of microscopic creatures in our daily lives by preparing scenarios. The groups were given one week for this assignment. The rubrics to be used to evaluate the work of both groups before the drama activity were distributed to the groups and the criteria to be carried out were reported. Some of the scenarios developed by the groups within the scope of drama activities are given in Appendix 1.

Both drama activities were conducted in the following two courses after the related course was conducted. The groups were guided by the teacher and the researcher in order to develop the scenarios of the drama studies to be prepared by the groups. After the drama activities, the students were provided to internalize the subject by discussing it with questions and answers.

\subsection{Analysis of the Data}

While evaluating the activities of the groups, the criteria and realization levels in the developed analytical rubric were taken into consideration. In this context, eight different drama activities by four groups were evaluated and graded. The evaluations were conducted by the researcher and the teacher who observed the drama activities. When evaluating the drama activities presented by the groups, the best expected performance in different criteria was scored as 4 points and the worst performance score as zero. In the evaluation of the drama activities with analytical rubric, the arithmetic average of the points given by the teacher and the researcher to the level of realization of the criteria was calculated. While the arithmetic means were taken, the half points were rounded to full points.

\section{Findings}

This section includes the evaluation of 8 drama activities conducted by the groups with rubric developed within the study. The explanations about the drama activities presented by the groups were presented to the reader with the names they gave to the scenarios developed by the groups.

\subsection{Findings from the Evaluation of Drama Activities Presented by Students on Vertebrate-Invertebrate Animals}

The results obtained from the evaluation of the drama activities presented by the groups with the developed analytical rubric are indicated in Table 2 below. 
Table 2. Findings obtained from Evaluation of the Presented Drama Activities related to the Classification of Vertebrate-Invertebrate Animals with Analytical Rubric

\begin{tabular}{ccccc}
\hline Criteria & $\begin{array}{c}\text { 1. } \\
\text { Group }\end{array}$ & $\begin{array}{c}\text { 2. } \\
\text { Group }\end{array}$ & $\begin{array}{c}\text { 3. } \\
\text { Group }\end{array}$ & $\begin{array}{c}\text { 4. } \\
\text { Group }\end{array}$ \\
\hline Scenario & 2 & 2 & 4 & 4 \\
\hline The content of the roles & 4 & 4 & 4 & 3 \\
\hline Sharing the roles & 3 & 3 & 4 & 3 \\
\hline Role playing & 4 & 4 & 4 & 4 \\
\hline Total & 13 & 13 & 16 & 14 \\
\hline
\end{tabular}

When the Table 2 is analyzed, it is seen that the first group who prepared the drama work called "Ali's Adventure" took exact score from the content of the roles and role play criteria, however, they couldn't take exact score because they had some faults in the scenario and sharing of the roles criteria. The total score of the group's drama activity from rubric evaluation is 13 .

It is seen that the second group who prepared the drama called "Ali's Venture" took exact score just like the first group from the content of the roles and role play criteria. However, they had some faults in scenario and role sharing criteria. The total score of the group's drama activity from rubric evaluation is 13 .

It is seen that the third group who prepared the drama called "Ali's Weekend" took 4 exact points from the scenario, content of the roles, sharing of the roles and role play criteria in the rubric and got 16 points at total.

It is seen that the fourth group who prepared the drama called "Ali Explores" took exact score from the scenario and role play criteria, however, they couldn't take exact score because they had some faults in the content of the roles and sharing of the roles criteria. The total score of the group's drama activity from rubric evaluation is 14 .

\subsection{Findings obtained from the Evaluation of the Drama Activities Presented by Students on the Effects of Microscopic Living Things in Our Daily Life}

Two of the drama studies prepared by the groups in the context of the effects of microscopic living things in our daily lives are related to the benefits of microscopic living things to our daily lives and the other two are related to their harms. The results obtained from the evaluation of the dramas of the groups by rubric are given in Table 3 .

Table 3. Findings from the evaluation of the drama activities that are presented about the beneficial and harmful effects of microscopic living things in our daily lives with analytical rubrics.

\begin{tabular}{ccccc}
\hline Criteria & $\begin{array}{c}\text { 1. } \\
\text { Group }\end{array}$ & $\begin{array}{c}\text { 2. } \\
\text { Group }\end{array}$ & $\begin{array}{c}\text { 3. } \\
\text { Group }\end{array}$ & $\begin{array}{c}\text { 4. } \\
\text { Group }\end{array}$ \\
\hline Scenario & 4 & 4 & 3 & 4 \\
The content of the roles & 3 & 4 & 4 & 4 \\
Sharing the roles & 3 & 4 & 3 & 4 \\
Role playing & 4 & 4 & 4 & 4 \\
\hline Total & 14 & 16 & 14 & 16 \\
\hline
\end{tabular}

When the Table 3 is analyzed, it is seen that the first group who prepared the drama work called "Defne's Illness" took exact score from the scenario and role play criteria, however, they had some faults in the content of the roles and sharing of the roles criteria. The total score of the group's drama activity from rubric evaluation is 14 .

It is seen that the second group who prepared the drama work called "Microscopic Living Things and Their Benefits" took 4 exact points from the scenario, content of the roles, sharing of the roles and role play criteria in the rubric and got 16 points at total.

It is seen that the first group who prepared the drama work called "Harmful Microscopic Living Things" took 3 points from the scenario and sharing of the roles criteria and 4 points from other criteria. The total score of the group's drama activity from rubric evaluation is 16 .

It is seen that the second group who prepared the drama work called "Beneficial Microscopic Living Things" took 4 exact points from the scenario, content of the roles, sharing of the roles and role play criteria in the rubric and got 16 points at total.

\section{Discussion and Result}

In this study, it is aimed to evaluate the drama activities conducted in $5^{\text {th }}$ grade science subjects with a developed rubric. When the activities of the groups related to the classification of vertebrate-invertebrate animals were evaluated, the third group that prepared the scenario named "Ali's Weekend" took 16 points from all the criteria in the rubric (Table 2). It was determined that other groups experienced some problems in realizing the criteria of "scenario", "content of roles", "sharing of roles" except for "role playing". It can be seen from Table 3 that the results of the evaluation of the drama activities performed by the groups about the beneficial and harmful effects of the microscopic living things in our daily lives are similar to the results of the evaluation of the drama activity related to the first acquisition. In the evaluations made about this acquisition, it is seen that the second and the fourth groups who prepared the scenarios "Defne's Illness" and "Microscopic Living Things and Their Benefits" scored 16 points and took full points from all criteria. Table 3 shows that other groups did not take full points from other criteria except for the role-playing criterion in rubric just like in the evaluation of previous acquisition. When these findings are taken into consideration, it can be concluded that all the drama activities performed by the groups are fully realized. However, when we look at all the drama activities conducted within the scope of the study, it is seen that the "scenario", "content of roles" and "sharing of roles" criteria in the rubric are not fully realized. It is noteworthy that all of the eight different drama activities in the rubric performed by the groups, only the role play criteria was completely realized. This may indicate that students are not used to assessing activities with rubrics that contain 
specific criteria. İpek [19] reported that the fact that some of the rubrics' criteria could not be performed by the students was attributed to the fact that the students were not used to the rubric evaluation. Although it is recommended to use rubrics to evaluate the work of students in projects such as drama, project, posters, banners, etc., it is known that teachers do not lean towards them and therefore do not use them in their courses [32;23;44]. Duran [12] found that the ratio of male teachers who use rubrics less or do not use them at all as a means of evaluation was $37 \%$, whereas this rate was $38.9 \%$ for female teachers. Similarly, it is stated in different studies in the literature that both teachers and pre-service teachers feel insufficient to prepare and use rubrics and that they give little place to rubrics in science courses $[30 ; 23 ; 45 ; 44]$. As a matter of fact, the subject teacher also stated in the informal interview that he did not prefer the evaluations made with the rubrics due to lack of time and lack of knowledge about preparing rubrics, therefore it can be said that this result of the study is parallel to the literature.

Another striking point in these studies is that students focus on product rather than process in drama activities. The fact that all of the groups took full scores only from the role play criteria in all of the drama activities related to both subjects supports this result. This finding supports the conclusion that the students mentioned above are not used to the evaluation of activities with rubrics that contain certain criteria. Özsevgec [33] reported that the students gave importance to the product rather than the process in the technological designs they prepared. Therefore, the result of the study is parallel to the literature.

\section{Recommendations}

It is determined in our study in which drama activities are evaluated with analytical rubrics that the students are not accustomed to rubric evaluation, focus on the product rather than process, and the course teachers feel themselves insufficient in terms of preparing rubrics. Teachers should be informed in detail about the importance of evaluating the activities with rubrics, developing and the use of rubrics. Students can better understand their performance criteria and levels by incorporating them into the development process of the rubrics.

This study, in which the drama activities prepared by the students are evaluated with analytical rubrics, has low validity as it was conducted with a limited sample group. The analytical rubric developed to evaluate drama activities within the scope of our study can be developed by using it in different studies carried out with a larger sample size in different courses and different grade levels with the utilization of the preliminary results of this study.

\section{REFERENCES}

[1] Adıgüzel, Ö. (2013). Eğitimde yaratıcı drama. Ankara: Pegem Akademi Yayıncılık, 45.

[2] Airasian, P. W. (2001). Classroom assessment: Concepts and applications. Boston: McGraw-Hill.

[3] Akbaş, H. Ş. (2011). Fen eğitiminde problem çözme stratejisi olarak drama uygulamalarının başarı, tutum, kavramsal anlama ve hatırlamaya etkisi, Marmara Üniversitesi Eğitim Bilimleri Enstitüsü İlköğretim Anabilim Dalı Fen Bilgisi Öğretmenliği Bilim Dalı, Yüksek Lisans Tezi, İstanbul.

[4] Akınoğlu, O., \& Akbaş, H.Ş. (2010). Fen Eğitiminde problem çözme stratejisi olarak drama uygulamalarının kavramsal anlamaya etkisi. International Conference on New Trends in Education and Their Implications, Antalya-Turkey. ss.360- 366

[5] Arieli, B. (2007). The Integration of Creatıve Drama Into Science Doctor of Philosophy Curriculum \& Instruction, College of Education Teachıng, Kansas State Unıversity, Manhattan, Kansas.

[6] Aslanoğlu, E. A. (2003). Öğretimde sunu becerilerinin değerlendirilmesinde dereceli puanlama anahtarı (dereceli puanlama anahtarı) kullanılmasına ilișkin bir araștırma. Yayımlanmamış Yüksek Lisans Tezi, Ankara Üniversitesi Eğitim Bilimleri Enstitüsü.

[7] Aydın Gürler, S. (2016). Kazanımlara yönelik dereceli puanlama anahtarlarının geliştirilmesi, kullanılması ve değerlendirmede objektifliğe katkısı, Fırat Üniversitesi Eğitim Bilimleri Enstitüsü İlköğretim Ana Bilim Dalı, Yayınlanmamış Doktora Tezi.

[8] Bahar, M., Nartgün, Z., Durmuş, S. ve Bıçak, B. (2006). Geleneksel-Alternatif Ölçme ve Değerlendirme Öğretmen El Kitabı, Pegem Yayıncılık, Ankara.

[9] Bandiera, M. (2007). Contributions from science education research, micro-organisms: Everyday Knowledge Predates and Contrasts with School Knowledge, Springer Netherlands.

[10] Brookhart, S. M. (1999). The Art and Science of Classroom Assessment: The Missing Part of Pedagogy. ASHE-ERIC Higher Education Report (Vol. 27, 69 No.1). Washington, DC: The George Washington University, Graduate School of Education and Human Development.

[11] Çepni, S. (2009). Araştırma ve Proje Çalışmalarına Giriş (Genişletilmiş 3. Bask1), Celepler Matbaacılık, Trabzon.

[12] Duran, U. (2017). Öğretmenlerinin alternatif ölçme değerlendirme yöntemlerinin kullanımına ilişkin öz yeterlik algılarının incelenmesi. Gaziantep Üniversitesi Eğitim Bilimleri Enstitüsü Sınıf Eğitim Ana Bilim Dalı, Yüksek Lisans Tezi, Gaziantep.

[13] Durdukoca, Ş. F. (2015). Okulöncesi öğretmen adaylarının bir ders ve öğretim tekniği olarak dramaya yönelik görüşlerinin incelenmesi. Erzincan Üniversitesi Ĕ̆itim Fakültesi Dergisi, 17(1), 153-174.

[14] Goodrich, A. H. (2001). The effects of instructional rubrics on learning to write. Current Issues in Education, 4, (4),27-31. 
[15] Hatipoğlu, Y.Y. (2006). İlköğretim 5. sinıf matematik ders konularının öğretiminde drama yönteminin öğrenci başarısına etkisi. Yayınlanmış Yüksek Lisans Tezi, Gazi Üniversitesi Eğitim Bilimleri Enstitüsü, Ankara.

[16] Hein, G.E. (1991). Constructivist Learning Theory: The Museum and The Needs of People, Paper presented at International Committee of Museum Educators (CECA) Conference, Jerusalem, Israel.

[17] Huang, D. (2004). Student's Conceptions of Animal Classification and Vertebrates, A Cross-Age Study, Chinese Journal of Science Education, 12,3,289-310.

[18] lhan, M. (2016). Açık uçlu sorularla yapılan ölçmelerde klasik test kuramı ve çok yüzeyli Rasch modeline göre hesaplanan yetenek kestirimlerinin karşılaştırılması. Hacettepe Üniversitesi Eğitim Fakültesi Dergisi, 31(2), 346-368. doi:10.16986/HUJE.2016015182.

[19] İpek, H. (2007). Sekizinci sınıf yaşamımızdaki elektrik ünitesine uygun rehber materyal geliştirilmesi ve etkililiğinin değerlendirilmesi, Yayımlanmamış Yüksek Lisans Tezi, KTÜ, Fen Bilimleri Enstitüsü, Trabzon.

[20] Kan, A. (2007). Performans değerlendirme sürecine katkıları açısından yeni program anlayışı içerisinde kullanılabilecek bir değerlendirme yaklașımı: Dereceli puanlama anahtarı puanlama yönergeleri. Kuram ve Uygulamada Ĕ̈itim Bilimleri, 7(1), 129-152.

[21] Kara, Y. \& Cam, F. (2007). Yaratıcı drama yönteminin bazı sosyal becerilerin kazandırılmasına etkisi. Hacettepe Üniversitesi Eğitim Fakültesi Dergisi, 32, s, 145-155.

[22] Kılınçaslan, H., \& Şimşek, P. Ö. (2015). 6. sınıf "Kuvvet ve Hareket" ünitesinde basamaklı öğretim yöntemi ve yaratıcı drama yönteminin erişi, tutuma ve kalıcılığa etkisi. Ĕgitim ve Bilim, 40(180). DOI: 10.15390/EB.2015.4380

[23] Kilmen, S. V. \& Çıkrıkçı-Demirtaşlı, N. (2009). Sınıf öğretmenlerinin ölçme ve değerlendirme ilkelerini uygulama düzeylerine ilişkin görüşleri. Ankara Üniversitesi, Ĕ̈itim Bilimleri Fakültesi Dergisi, 42 (2), 27-55.

[24] Kutlu, Ö., Doğan, C. D. ve Karakaya, İ. (2014). Ölçme ve değerlendirme: Performansa ve portfolyoya dayall durum belirleme. Ankara: Pegem Akademi Yayıncılık.

[25] Kuyumcu, N. (2007). İlköğretimde Oyun ve Ders, Morpa Kültür Yayınları, İstanbul.

[26] MEB. (2006). Milli Eğitim Bakanlığı, Ortaöğretim Genel Müdürlüğü, Eğitsel oyunlar dersi öğretim programı, Ankara.

[27] MEB. (2018). Fen Bilimleri Dersi Öğretim Programı (İlkokul ve Ortaokul 3, 4, 5, 6, 7. ve 8. Sinıflar), Ankara.

[28] Ogan-Bekiroglu, F. (2004). Ne kadar başarllı? Klasik ve alternatif ölçme değerlendirme yöntemleri ve fizikte uygulamalar, Nobel Yayın Dağıtım, Ankara.

[29] Oğur, B. (2005). Fen bilgisi dersinde, canlıların iç yapısına yolculuk ve vücudumda neler var? çevremizi nasıl alg1liyoruz? ünitelerinde drama entegrasyonunu ögrencilerin fen başarılarına etkisi, Yüksel Lisans Tezi, A.İ.B.Ü., Sosyal Bilimler Enstitüsü, Bolu.

[30] Okur, M. (2009). Kavramsal değișimi sağlayan farklı metotların karşılaştırılması: sesin yayılması konusu örneği,
Yüksek Lisans Tezi, KTÜ, Fen Bilimleri Enstitüsü, Trabzon.

[31] Orsmond, P., Merry, S., \& Reiling, K. (2000). The use of student derived marking criteria in peer and self-assessment. Assessment and Evaluation in Higher Education, 25, p. 23-38.

[32] Öz, B. (2007). 2001 İlköğretim fen bilgisi dersi ve 2005 ilköğretim fen ve teknoloji dersi programlarına ilişkin öğretmen görüşleri, Yüksek Lisans Tezi, Çukurova Üniversitesi, Sosyal Bilimler Enstitüsü, Adana.

[33] Özsevgeç, T. (2007). İlköğretim 5. sınıf kuvvet ve hareket ünitesine yönelik 5e modeline göre geliștirilen rehber materyallerin etkililiklerinin belirlenmesi, Doktora Tezi, KTÜ, Fen Bilimleri Enstitüsü, Trabzon.

[34] Parlak, B. (2010). Öğrenci performansının belirlenmesinde puanlama anahtarı ve dereceli puanlama anahtarının karşılaştırılması. Hacettepe Üniversitesi, Yüksek Lisans Tezi, Ankara.

[35] Popham, W. J. (1997). What's stil wrong- and what's stil right with rubric. Educational Leadership, 55, p, 72-75.

[36] Sağırlı, H., Gürdal, A. (2002). Fen bilgisi dersinde drama tekniğinin öğrenci başarısına etkisi, M. ̈. Atatürk Eğitim Fakültesi Eğitim Bilimleri Dergisi, 15, 213-224.

[37] Sarığlu, T. \& Kartal, G. (2017). Bir yöntem olarak drama bilişim teknolojileri öğretiminde iyi bir seçenek olabilir mi?, Illköğretim Online, 16(1), s,366-376.

[38] Savaşçı, B., \& Özdemir, P. Ș. (2012). İlköğretim fen bilgisi dersi 7. Sinıf uzay bilmecesi ünitesinin yaratıcı drama yöntemi ile ele alınması. Yaratıcı Drama Dergisi, 7(14), 19-37.

[39] Senemoğlu, N. (2018). Gelişim öğrenme ve ögrretim kuramdan uygulamaya, Anı Yayıncılık, 1. Baskı, Ankara.

[40] Sevinç, M. (2004). Erken çocukluk gelișimi ve eğitimde oyun, Morpa Yayınc1lık, İstanbul.

[41] Sezer, S. (2006). Öğrencinin akademik başarısının belirlenmesinde tamamlayıcı değerlendirme aracı olarak rubrik kullanımı üzerinde bir araştırma, Pamukkale Ünv. Ĕ̈itim Fakültesi Dergisi, 18, 6-10.

[42] Sezgin, B. (2008). Doğa koleji’nde oyun drama tiyatro etkinlikleri müfredat çalışması, İyi İşler Matbaası, İstanbul.

[43] Sivrikaya, E. 2005. Canlıların çeşitliliği ve sınıflandırılması ünitesine yönelik kavramsal değișim metinlerinin, başarıya etkisi, KTÜ., Fen Bilimleri Enstitüsü, Orta Öğretim Fen ve Matemetik Alanları Eğitimi Anabilim Dalı, Trabzon.

[44] Şahin, Ç. \&; Öztürk Abalı, Y. (2015). Opınıons of prospective class teachers about their proficiency in using alternative assessmentevaluation instruments, Journal of Theory \& Practice in Education (JTPE) ,11 (2), p, 438-459. $22 \mathrm{p}$.

[45] Saşmaz Ören, F., Ormanc1, Ü. \& Evrekli, E. (2014). Öğretmen adaylarının tercih ettikleri alternatif ölçme-değerlendirme yaklaşımları ile bu yaklaşımlara ilişkin öz-yeterlilikleri, Ĕgitim ve bilim, 39 (173), s103-117

[46] Şenel, T. (2008). Fen ve teknoloji öğretmenleri için alternatif ölçme ve değerlendirme tekniklerine yönelik bir 
hizmet içi eğitim programının etkililiğinin araştırılması, Yüksek Lisans Tezi, KTÜ, Trabzon.

[47] Taşkın, T., \& Moğol, S. (2016). Fizik konularının ögretiminde bir yöntem olarak yaratıcı dramanın kullanımına ilişkin öğretmen adaylarının. Gazi Ĕ̆itim Bilimleri Dergisi, 2(3). 193 - 210.

[48] Tekindal, S (Ed.). (2008). Ĕgitimde ölçme ve değerlendirme, Pegem Akademi, Ankara.

[49] URL-1, Challenging Misconceptions About Microbes. $\mathrm{http} / / / \mathrm{www}$. scienceonline.co.uk/tour /misconceptions.html, 4 Kasim 2008.

[50] Ünüvar, T. (2007). İlköğretim 6. sınıf fen bilgisi dersinde canlının yapısına yolculuk ünitesinde yaratıcı drama ile öğretimin öğrencilerin erişisine etkisi, Yüksek Lisans Tezi, S.Ü., Fen Bilimleri Enstitüsü, Konya.

[51] Yager, R. (1991). The constructivist learning model towards real form in science education, the science teacher, 58, (6), p 52-57.

[52] Yalım, N. (2003). İlköğretim dördüncü sınıf fen bilgisi dersinin yaratıcı drama yöntemi ile öğretiminin öğrencilerin akademik başarılarına etkisi. Eskişehir Anadolu Üniversitesi, Eğitim Bilimleri Enstitüsü, Yüksek Lisans Tezi, Eskişehir.

[53] Yapıc1, H. (2015). Sosyal bilgiler öğretmenlerinin drama yöntemini kullanmaya yönelik öz yeterlilikleri. The Journal of Academic Social Science Studies, 38, 371- 381

[54] Yen, C.F., Yao, T.W. ve Mintzesc, J. J., 2007. Research Report Taiwanese Students' Alternative Conceptions of Animal Biodiversity, International Journal of Science Education, 29, 4, 535-553.

[55] Zorbaz, K.Z. (2013). Yazılı anlatımın puanlanması. Abant İzzet Baysal Üniversitesi Eğitim Fakültesi Dergisi, 13(1): 178-192

\footnotetext{
${ }^{i}$ This study was generated from the first author's doctoral thesis.
} 